\title{
REVIEW
}

\section{Prevention of Serious Respiratory Syncytial Virus-Related Illness. II: Immunoprophylaxis}

Jessie R. Groothuis · J. Michael Hoopes · Val G. Hemming

Received: September 30, 2010 / Published online: February 4, 2011

(c) The Author(s) 2011. This article is published with open access at Springerlink.com

\section{ABSTRACT}

Respiratory syncytial virus (RSV) causes significant morbidity in very young children, preterm infants with and without chronic lung disease, and children with hemodynamically significant congenital heart disease. In the absence of a safe and effective vaccine, alternative means of protecting high-risk infants and young children from serious RSV illness have been studied. Clinical observations and animal model data over the past 30 years suggested that RSV immunoglobulin G (IgG) neutralizing antibodies might offer protection from severe RSV lower respiratory tract disease. Transfer of adequate amounts of IgG to the fetus does not occur efficiently until the third trimester of pregnancy, which helps to explain why premature infants are at high risk of serious RSV illness. Efforts shifted toward the prophylactic monthly administration of standard immunoglobulins and, later, of RSV-enriched immunoglobulin in selected high-risk infants and

Jessie R. Groothuis $(\bowtie) \cdot J$. Michael Hoopes MedImmune, LLC, 1 MedImmune Way, Gaithersburg, MD 20878, USA. Email: GroothuisJ@MedImmune.com

Val G. Hemming

Retired, Uniformed Services University of Health

Sciences, Bethesda, MD, USA young children. Although this approach proved effective, RSV-enriched immune globulin was not suitable for all patients and administration was labor intensive. The development of palivizumab, a monoclonal antibody that can bind to a specific antigenic site on the virus and prevent cell-to-cell spread of infection has since become the mainstay of RSV illness prevention in preterm infants and those with significant congenital heart disease. Palivizumab, the only monoclonal antibody approved for the prevention of RSV lower respiratory tract disease must be administered monthly throughout the RSV season and does not always prevent serious RSV illness. Further research to develop more effective and less labor-intensive immunoprophylactic agents is ongoing.

Keywords: children; history; immunoglobulin; immunoprophylaxis; monoclonal antibody; palivizumab; respiratory syncytial virus; vaccine

\section{INTRODUCTION}

In the first part of this series, we discussed the identification of respiratory syncytial virus (RSV), the epidemiology of RSV infection, 
Table 1. Immunoprophylaxis studies.

\begin{tabular}{|c|c|c|c|}
\hline $\begin{array}{l}\text { First author, } \\
\text { year, } \\
\text { reference }\end{array}$ & Study design & Findings & Comments \\
\hline \multicolumn{4}{|c|}{ Standard immune globulin intravenous (IGIV) } \\
\hline $\begin{array}{l}\text { Hemming } \\
1987^{6}\end{array}$ & $\begin{array}{l}\text { R, DB, PC, pilot study in } 35 \text { infants } \\
\text { and children infected with RSV. } \\
\text { IGIV. }\end{array}$ & $\begin{array}{l}\text { Significant reductions in nasal shedding } \\
\text { and improvements in oximetry; no } \\
\text { significant reductions in hospital stay, } \\
\text { supplemental } \mathrm{O}_{2} \text {, or clinical symptoms. }\end{array}$ & $\begin{array}{l}\text { This was a treatment trial. IGIV was } \\
\text { well tolerated. No further clinical } \\
\text { studies were conducted with this } \\
\text { formulation. }\end{array}$ \\
\hline $\begin{array}{l}\text { Groothuis } \\
1991^{7}\end{array}$ & $\begin{array}{l}\text { Phase 1, open-label study in } 23 \text { at-risk } \\
\text { (CLD, CHD) children studied over } \\
\text { two RSV seasons. } \\
\text { IGIV administered monthly at three } \\
\text { dose levels over } 4 \text { months. }\end{array}$ & $\begin{array}{l}12 \text { children developed RSV infection } \\
\text { (nine in season } 1 \text { and three in season } 2 \text { ), } \\
11 \text { of whom had mild disease. IGIV was } \\
\text { relatively well tolerated. }\end{array}$ & $\begin{array}{l}\text { Neutralizing titers achieved were } \\
\text { considered suboptimal to prevent } \\
\text { RSV infection. }\end{array}$ \\
\hline $\begin{array}{l}\text { Meissner } \\
1993^{8}\end{array}$ & $\begin{array}{l}\mathrm{R} \text {, controlled trial in } 49 \text { at-risk (CLD, } \\
\text { CHD) children; } 25 \text { were given IGIV } \\
\text { and } 24 \text { received no treatment. } \\
\text { IGIV administered monthly at one } \\
\text { dose level over } 5 \text { months. }\end{array}$ & $\begin{array}{l}\text { A similar number of patients in each } \\
\text { group had culture-proven RSV infection, } \\
\text { but children in the IGIV group spent } \\
\text { fewer days in the hospital ( } 35 \text { versus } \\
51 \text { days, respectively). IGIV was } \\
\text { well tolerated. }\end{array}$ & $\begin{array}{l}\text { The standard IGIV formulation } \\
\text { studied did not contain sufficient } \\
\text { RSV neutralizing antibody to confer } \\
\text { protection against severe RSV disease. }\end{array}$ \\
\hline \multicolumn{4}{|c|}{ RSV-enriched IGIV (RSV-IGIV) } \\
\hline $\begin{array}{l}\text { Groothuis } \\
1993^{9}\end{array}$ & $\begin{array}{l}\text { R, controlled trial of two dose levels } \\
(150 \text { and } 750 \mathrm{mg} / \mathrm{kg} \text { ) of RSV-IGIV } \\
\text { administered monthly versus no } \\
\text { treatment in } 160 \text { high-risk (CLD, } \\
\text { CHD, premature delivery) children } \\
<48 \text { months of age. }\end{array}$ & $\begin{array}{l}\text { Children in the high-dose group } \\
\text { fared significantly better than other } \\
\text { groups with respect to number of } \\
\text { lower respiratory tract infections and } \\
\text { hospitalizations. } \\
\text { RSV-IGIV was well tolerated. }\end{array}$ & $\begin{array}{l}\text { Mean age of children who received } \\
\text { active treatment was } 8 \text { months, } \\
\text { although six children were } \\
\geq 24 \text { months at study entry. } \\
\text { Question as to the suitability of RSV- } \\
\text { IGIV for use in children with CHD. }\end{array}$ \\
\hline $\begin{array}{l}\text { PREVENT } \\
1997^{10}\end{array}$ & $\begin{array}{l}\text { R, DB, PC trial of RSV-IGIV } \\
(750 \mathrm{mg} / \mathrm{kg} ; n=250) \text { administered } \\
\text { monthly to } 510 \text { high-risk children } \\
\text { (CLD and/or prematurity) for } \\
\text { prevention of hospitalization. }\end{array}$ & $\begin{array}{l}\text { Incidence of RSV-related hospitalization } \\
\text { reduced by } 41 \% \text { versus placebo } \\
\text { ( } 8 \% \text { versus } 13.5 \% \text { ). Hospitalization for } \\
\text { respiratory illness of any cause reduced } \\
\text { by } 38 \% \text {. } \\
\text { Fluid overload was a problem for } \\
\text { some patients. }\end{array}$ & $\begin{array}{l}\text { First study to specifically address } \\
\text { impact of immunoprophylaxis on } \\
\text { hospitalizations. } \\
\text { Pivotal trial that supported licensure } \\
\text { of RespiGam }{ }^{\circledR} \text {. }\end{array}$ \\
\hline $\begin{array}{l}\text { Simoes } \\
1998^{11}\end{array}$ & $\begin{array}{l}\text { R, controlled trial of RSV-IGIV } \\
(750 \mathrm{mg} / \mathrm{kg} ; 50 \mathrm{mg} / \mathrm{mL} ; n=202) \\
\text { administered monthly versus } \\
\text { no treatment for prevention of } \\
\text { hospitalization in children }<4 \text { years } \\
\text { of age with CHD. }\end{array}$ & $\begin{array}{l}\text { RSV-IGIV failed to meet the primary } \\
\text { efficacy endpoint, although a significant } \\
\text { decrease in the incidence of hospital- } \\
\text { ization for any respiratory tract illness } \\
\text { was noted. } \\
\text { There was a significantly higher frequency } \\
\text { of unanticipated cyanotic episodes and } \\
\text { poor outcomes after surgery among } \\
\text { children with cyanotic CHD. }\end{array}$ & $\begin{array}{l}\text { Due to poor efficacy and safety issues, } \\
\text { no further studies of RSV-IGIV were } \\
\text { conducted in children with CHD. }\end{array}$ \\
\hline
\end{tabular}

(continued on next page) 
Table 1. Immunoprophylaxis studies. (Continued)

\begin{tabular}{|c|c|c|c|}
\hline $\begin{array}{l}\text { First author, } \\
\text { year, } \\
\text { reference }\end{array}$ & Study design & Findings & Comments \\
\hline \multicolumn{4}{|l|}{ Palivizumab } \\
\hline $\begin{array}{l}\text { IMpact-RSV } \\
\text { Study Group } \\
1998^{12}\end{array}$ & $\begin{array}{l}\text { R, DB, PC, MC trial of palivizumab } \\
(15 \mathrm{mg} / \mathrm{kg} ; n=1002) \text { administered } \\
\text { monthly to high-risk children } \\
\text { (prematurity, CLD) for prevention } \\
\text { of hospitalization. }\end{array}$ & $\begin{array}{l}\text { Palivizumab found to significantly reduce } \\
(55 \%) \text { the incidence of RSV-related } \\
\text { hospitalization overall and when analyzed } \\
\text { by subgroup within each high-risk cohort. } \\
\text { Palivizumab was well tolerated. }\end{array}$ & $\begin{array}{l}\text { Pivotal phase } 3 \text { trial upon which } \\
\text { initial licensure of Synagis }{ }^{\circledR} \text { was } \\
\text { based. }\end{array}$ \\
\hline $\begin{array}{l}\text { Feltes } \\
2003^{13}\end{array}$ & $\begin{array}{l}\text { R, DB, PC, MC trial of palivizumab } \\
(15 \mathrm{mg} / \mathrm{kg} ; n=639) \text { administered } \\
\text { monthly to children with CHD for } \\
\text { prevention of hospitalization. }\end{array}$ & & $\begin{array}{l}\text { Pivotal trial for use in high-risk } \\
\text { children with CHD. }\end{array}$ \\
\hline \multicolumn{4}{|l|}{ Motavizumab } \\
\hline $\begin{array}{l}\text { Carbonell- } \\
\text { Estrany } \\
2010^{14}\end{array}$ & $\begin{array}{l}\mathrm{R}, \mathrm{DB}, \mathrm{MC} \text { trial of motavizumab } \\
(15 \mathrm{mg} / \mathrm{kg} ; n=3329) \text { versus } \\
\text { palivizumab }(15 \mathrm{mg} / \mathrm{kg} ; n=3306) \\
\text { administered monthly to high-risk } \\
\text { children (prematurity, CLD) for } \\
\text { prevention of hospitalization and } \\
\text { MALRIs. }\end{array}$ & $\begin{array}{l}\text { Motavizumab recipients had a } 26 \% \text { relative } \\
\text { reduction in RSV hospitalization versus } \\
\text { palivizumab (met noninferiority endpoint). } \\
\text { Motavizumab achieved a significant } 50 \% \\
\text { relative reduction versus palivizumab for } \\
\text { prevention of RSV MALRI. } \\
\text { Cutaneous adverse events were more } \\
\text { common in the motavizumab cohort } \\
\text { (7.2\% versus } 5.1 \%) \text {. }\end{array}$ & $\begin{array}{l}\text { Phase } 3 \text { trial employed a noninferio- } \\
\text { rity design. }\end{array}$ \\
\hline $\begin{array}{l}\text { Feltes } \\
2010^{15}\end{array}$ & $\begin{array}{l}\mathrm{R}, \mathrm{DB}, \mathrm{MC} \text { trial of motavizumab } \\
(15 \mathrm{mg} / \mathrm{kg} ; n=623) \text { versus } \\
\text { palivizumab }(15 \mathrm{mg} / \mathrm{kg} ; n=612) \\
\text { administered monthly to children } \\
\text { with hemodynamically significant } \\
\text { CHD for prevention of hospitaliz- } \\
\text { ation and MALRIs. }\end{array}$ & $\begin{array}{l}\text { Motavizumab recipients had a } 25 \% \text { relative } \\
\text { reduction in RSV hospitalization versus } \\
\text { palivizumab. } \\
\text { Motavizumab achieved a } 50 \% \text { relative } \\
\text { reduction versus palivizumab for prevention } \\
\text { of RSV MALRI. }\end{array}$ & \\
\hline $\begin{array}{l}\text { Chandran } \\
2008^{16}\end{array}$ & $\begin{array}{l}\text { R, DB, PC, MC trial of motavizumab } \\
(15 \mathrm{mg} / \mathrm{kg} ; n=938) \text { versus placebo } \\
(n=472) \text { administered monthly for } \\
\text { prevention of hospitalization and } \\
\text { MALRIs in term Native American } \\
\text { infants. }\end{array}$ & $\begin{array}{l}\text { Motavizumab recipients had significant } \\
\text { reductions in hospitalization ( } 83 \%) \text { and } \\
\text { MALRI }(71 \%) \text { versus placebo. }\end{array}$ & \\
\hline
\end{tabular}

$\mathrm{CHD}=$ congenital heart disease; $\mathrm{CLD}=$ chronic lung disease of prematurity; $\mathrm{DB}=$ double-blind; MALRI=medically attended lower respiratory infection; $\mathrm{MC}=$ multicenter; $\mathrm{PC}=$ placebo-controlled; $\mathrm{R}=$ randomized; $\mathrm{RSV}=$ respiratory syncytial virus. 
and failed efforts to prevent RSV disease with vaccines to date. Given the challenges posed in the discovery of a universally safe and effective vaccine to protect young infants against severe RSV, efforts shifted to the development of passive immunoprophylaxis in children at particular risk for RSV lower respiratory infection. ${ }^{1}$ Three important human observations suggested that this method of immunization would be efficacious. The first was the observation that there was an inverse correlation between the severity of RSVrelated pneumonia and the level of maternal neutralizing antibody in young infants. ${ }^{2}$ Second was the observation of the inverse relationship between serum neutralizing antibody and rate of RSV infection. ${ }^{3}$ Finally, a positive association was observed between the amount of serum immunoglobulin (Ig) G directed to the RSV F protein that offered protection against RSV reinfection and decreased illness severity in children. ${ }^{4}$

An important link between animal models of immunoprophylaxis and human infants was the experience with "Baby Moose", a critically ill Native American infant admitted to Fitzsimmons Army Medical Center in Denver in 1983 for a presumed group B Streptococcus infection. ${ }^{5}$ The infant was given immune globulin intravenous (IGIV) and improved rapidly. Surprisingly, however, the infant was found to be negative for group B Streptococcus but tested positive for RSV. This serendipitous event prompted the first human studies of IGIV for potential prevention and therapy of RSV in high-risk infants and young children. RSV immunoprophylaxis has since evolved from the initial licensure of an RSV-enriched immune globulin administered by intravenous infusion to more potent and specific monoclonal antibodies (MAbs) given by intramuscular injection (Table 1). However, there is much room for additional scientific discovery in this area and need for agents that can afford nearly complete protection to all high-risk groups in fewer doses.

\section{STANDARD IMMUNE GLOBULIN INTRAVENOUS}

Because not all lots of commercial standard human IGIV contain significant levels of RSVneutralizing antibodies, an initial study was conducted to determine if standard IGIV could prevent RSV infection in the lungs of cotton rats. ${ }^{17}$ Four lots of IGIV (Sandoglobulin ${ }^{\circledR}$, Sandoz Pharmaceuticals, East Hanover, NJ, USA; neutralization test titers between 2702 and 9344) were tested and shown to protect against pulmonary infection when administered before RSV challenge. The level of virus reduction was directly linked to the neutralizing antibody titer in cotton rat serum and was always greater in the lungs compared with the nose. Encouraging results from this trial and others ${ }^{18}$ prompted the conduct of a double-blind, placebo-controlled, pilot study of the effects of IGIV (neutralizing antibody titers approximately 1:5000) for the treatment of RSV infection in 35 hospitalized infants and children. ${ }^{6}$ Each child received $2 \mathrm{~g}$ of study drug (IGIV or albumin placebo) per $\mathrm{kg}$ of bodyweight infused over 12-24 hours. The IGIV-treated group experienced significantly greater reductions in nasopharyngeal RSV infectivity titers $(P<0.01)$ and nasal shedding and significant improvement in oximetry results $(P<0.05)$ compared with controls. Although complete clearance of RSV was observed in more children in the IGIV group versus controls (77\% versus 50\%, respectively), neither these differences, nor differences in clinical symptoms, duration of hospitalization, or supplemental oxygen requirements were significant between groups. 
A prospective, open-label trial was undertaken to determine if four monthly infusions of IGIV (Gamimune-N ${ }^{\circledR}$, Cutter Biological, Berkeley, CA, USA; neutralizing antibody titers of $1: 1125$ and $1: 1075)$ could protect 23 high-risk children with chronic lung disease of prematurity (CLD; $n=15)$, congenital heart disease (CHD; $n=5)$, or a combination of both $(n=3)$ from three major cities against RSV disease during the season in which it was administered and the following RSV season when no treatment was given. ${ }^{7}$ The dose of IGIV $(500,600$, or $750 \mathrm{mg} / \mathrm{kg}$ ) varied by treatment location. Active RSV infection was detected in nine children during the first season and in three children during season 2 . Clinical features of disease were relatively mild in 11 cases, and only two children required hospitalization. Although a target RSV antibody titer of $\geq 1: 100$ was achieved at the highest dose given, the investigators concluded that, based on data in the cotton rat, this is likely too low for adequate prophylaxis and that an RSV-enriched (RSV-IGIV) formulation should be developed and studied.

Meissner and associates conducted a prospective, randomized, controlled trial of IGIV (neutralizing antibody titer of 1:950) to evaluate protection against RSV illness when administered monthly at a dose of $500 \mathrm{mg} / \mathrm{kg}$ for five doses to 49 high-risk children (25 active treatment; average age 4.7 months) with CLD or CHD. ${ }^{8}$ Five patients in each group had culture-proven RSV infections, but there was a trend toward less severe disease as defined by fewer total days of hospitalization in the active treatment group (35 versus 51 days). The average peak titer was 1:124, which was similar to that achieved in the study by Groothuis et al. on a comparable IGIV formulation. ${ }^{7}$ The authors noted that standard IGIV is adequately tolerated in the intended population but does not contain sufficient RSV neutralizing antibody to prevent lower respiratory illness. Given the large volume of fluid that would be required for infusion to yield adequate neutralizing antibody titers, further study of standard IGIV was halted in favor of RSV-IGIV.

\section{RSV-ENRICHED IMMUNE GLOBULIN INTRAVENOUS}

As a result of insufficient antibody content and the poor efficacy observed with standard IGIV for RSV prophylaxis, efforts shifted to the development of an enriched hyperimmune RSV globulin produced from pooled human plasma that contained significantly greater RSV neutralizing activity. ${ }^{19}$ A landmark study in the cotton rat eloquently demonstrated that the serum neutralizing antibody titer and neutralizing antibody concentration needed to lower RSV concentration in the lungs by $99 \%$ was approximately a 10th of the amount required to achieve similar reduction in the nose (390 versus 3500, respectively, and $1320 \mathrm{MU} /$ $\mathrm{mL}$ versus $13,000 \mathrm{MU} / \mathrm{mL}) .{ }^{20}$ In this model, RSV-IGIV was shown to be 10 -fold more potent than IGIV in reducing pulmonary titers by 2 logs (indicative of 99\% virus reduction), although the dose of RSV-IGIV required for these effects in the nose was 10 times greater than that required to produce similar effects in the lung. Based on these findings, it was anticipated that RSV-IGIV would offer clinical benefit over IGIV for prevention of serious RSV lower respiratory tract disease.

To test the hypothesis that RSV infection of the lower respiratory tract could be prevented in high-risk children, Groothuis et al. conducted a randomized, controlled trial of two dose levels of RSV-IGIV $(150 \mathrm{mg} / \mathrm{kg}, n=79 ; 750 \mathrm{mg} / \mathrm{kg}$, $n=81$ ) administered monthly versus no 
treatment during one RSV season to children $<48$ months of age with CHD or CLD or who were born prematurely. ${ }^{9}$ Four lots of lyophilized RSV-IGIV with titers ranging from 1:2400 to 1:8073 were selected for use. Children in the high-dose group fared significantly better than other cohorts with respect to reduction in the incidence and severity of RSV lower respiratory tract infection, percentage hospitalized, and extent and severity of hospitalization. Overall, preterm infants experienced the greatest effects from treatment. Trough serum titers of RSVneutralizing antibody generally exceeded 1:200 and RSV-IGIV was well tolerated. The researchers concluded that RSV-IGIV deserves further study but that other methods of prophylaxis such as the intramuscular administration of MAbs should also be explored, especially in children with cardiac disease.

Following the success of early phase studies with RSV-IGIV, a pivotal, randomized, doubleblind, placebo-controlled trial was undertaken to assess the safety and efficacy of monthly infusions of RSV-IGIV $(750 \mathrm{mg} / \mathrm{kg}$ ) for reduction of the incidence of RSV-related hospitalization in 510 premature infants and infants with CLD. ${ }^{10}$ This study employed entry criteria and endpoints (ie, cut-off ages by diagnosis, reduction in RSVrelated hospitalization) that have become standards for future immunoprophylaxis studies. RSV-IGIV significantly reduced the incidence of RSV hospitalization versus placebo by $41 \%$ ( $8 \%$ versus $13.5 \%$, respectively; $P=0.047$ ), number of total days of RSV hospitalization by $53 \%(P=0.045)$, severity of RSV illness while hospitalized $(P=0.049)$, and overall respiratory hospitalizations $(P=0.005)$. Fewer RSV hospitalizations were noted in those given RSV-IGIV for all subgroups analyzed (eg, age, weight, sex, underlying diagnoses). However, the expansive fluid volume necessary for infusion was problematic in some patients and occasionally required fluid overload management with diuretics.

The suitability of RSV-IGIV for prevention of RSV-associated hospitalization in cardiac patients was separately assessed in a randomized controlled trial in 416 children $<4$ years of age with CHD or cardiomyopathy. ${ }^{11}$ RSV-IGIV was infused monthly at a dose of $750 \mathrm{mg} / \mathrm{kg}$ during one RSV season and the control group ( $n=214)$ received no treatment. Children were classified into one of four cardiac subgroups representative of their cardiac defect. Trough geometric mean neutralizing antibody titers increased $>10$-fold (from 40 to 445) from baseline to after the fourth dose. Although children who received RSV-IGIV had significantly fewer acute respiratory illnesses and hospitalizations for all respiratory causes, no significant differences were noted between the RSV-IGIV and control group with respect to the primary efficacy endpoint of RSV-related hospitalizations (10\% versus $15 \%$, respectively; $P=0.16 ; 31 \%$ reduction). The most significant finding on subgroup analysis was that children with underlying pulmonary hypertension were more likely to be hospitalized for RSV-related disease than other children. Because of a significant increase in unanticipated cyanotic events as well as an increased frequency of poor outcomes after cardiac surgery in children with right-to-left cardiac shunts in the RSVIGIV group, coupled with the failure to meet the primary efficacy endpoint, no further studies of RSV-IGIV were undertaken in this patient population.

The role of RSV-IGIV as a therapeutic option for treatment of severe, RSV-related illness was studied in a double-blind trial in 107 highrisk children $<2$ years of age (ie, CLD, CHD, or prematurity). ${ }^{21}$ Patients were randomized to treatment with a single infusion of RSV-IGIV 
$1500 \mathrm{mg} / \mathrm{kg}$ or placebo and characteristics of their hospitalization with respect to duration and severity were assessed. Although the severity of disease was greater in patients initially assigned to RSV-IGIV at study outset, results were adjusted to take this imbalance into consideration. No significant differences were noted between treatments and treatment subgroups for any of the outcome variables studied. A likely explanation for these findings is that after the virus penetrates the respiratory epithelial cells it is resistant to humoral immune effects whereas prophylactic immune therapy neutralizes the virus before cellular penetration and disease progression occurs. Following the results of this study, no further treatment trials of RSV-IGIV were conducted.

RSV-IGIV was approved for licensure in 1996 under the brand name RespiGam ${ }^{\circledR}$ (MedImmune, LLC, Gaithersburg, MD, USA), for prevention of serious RSV disease in preterm infants with and without CLD, but was contraindicated for use in children with CHD. RSV-IGIV was labor intensive to administer and impractical to use in many institutions because it had to be infused intravenously in a large volume of fluid (750 mg/kg; $15 \mathrm{~mL} / \mathrm{kg}$ ) over 2 to 4 hours. As a polyclonal IgG product, RSV-IGIV was produced from isolation of RSV antibodies from human blood and posed the potential for the transmission of blood-borne infections and interference with the routine administration of live pediatric vaccines (eg, measles, mumps, rubella). Thus, although RSV-IGIV was an important first step in the prevention of RSV lower respiratory tract infection, its many shortcomings prompted additional research for simpler and more effective types of immunoprophylaxis. Following the availability of a more suitable alternative, RSV-IGIV was voluntarily withdrawn from the marketplace in 2003.

\section{DEVELOPMENT OF MONOCLONAL ANTIBODIES FOR RSV IMMUNOPROPHYLAXIS}

To overcome the many drawbacks associated with RSV-IGIV therapy, efforts switched to the development of highly potent RSV-neutralizing MAbs that possessed greater viral neutralizing activity than RSV-IGIV and could be administered by intramuscular injection. The fusion (F) and G surface glycoproteins on the RSV virion are known to mediate viral fusion and attachment of the viral envelope with host cells, respectively, and became logical targets for MAb research. Of these, the F protein displays a higher degree of homogeneity in amino acid sequences among all RSV isolates, ${ }^{22,23}$ and blockage of specific binding sites on this antigen should halt cell-tocell transmission and syncytia formation. ${ }^{24}$

Ideally, a MAb intended for repeat administration should largely consist of human components to avoid generation of a human anti-mouse antibody response and to retain a favorable pharmacokinetic profile that would allow monthly dosing throughout the respiratory season. Three humanized MAbs (MEDI-493, also known as palivizumab, RSHZ19/SB209763, and HNK20) were initially developed in the 1990s, and each targeted a distinct neutralizing epitope on the F glycoprotein. ${ }^{25-27}$ HNK20 was a mouse IgA MAb developed as a nose drop given daily. Unfortunately, a phase 3 study failed to show a significant reduction in RSV hospitalization and further development was halted. ${ }^{28}$ Both palivizumab and RSHZ19 were IgG1-based MAbs intended for intramuscular administration. Pharmacodynamic and clinical pharmacokinetic studies showed each agent possessed potent fusion-inhibiting activity and similar half-lives that allowed for oncemonthly dosing. ${ }^{25,29-32}$ In comparative studies, palivizumab was consistently four to five times 
more potent than RSHZ19 in antigen binding, RSV neutralization, and fusion inhibition assays, and two to four times more potent in inhibiting RSV replication in the cotton rat model. ${ }^{33}$ The doses of each MAb that were eventually selected for study in late-phase human trials $(15 \mathrm{mg} / \mathrm{kg}$ for palivizumab and $10 \mathrm{mg} / \mathrm{kg}$ for RSHZ19) would suggest a bias in favor of palivizumab in terms of clinical outcomes. Indeed, RSHZ19 failed to confer significant protection against RSV lower respiratory tract disease in at-risk infants. ${ }^{33,34}$ Higher-dose studies were not initiated, and RSHZ19 was never licensed in any worldwide market. Additional trials conducted with palivizumab provided further evidence of the utility of MAbs for prevention of serious RSV lower respiratory illness.

\section{MEDI-493/PALIVIZUMAB}

Palivizumab was constructed by grafting the six complementarity determining regions (CDRs) of a mouse MAb (ie, MAb 1129) to human frameworks, which resulted in a composite of human (95\%) and murine (5\%) antibody sequences. ${ }^{25}$ MAb 1129 was initially derived from mice immunized with a specific RSV A2 strain and subsequently subjected to successive inoculations of recombinant F protein and infusion of purified RSV A2. ${ }^{24}$ A mouse 1129 hybridoma, which secreted an RSV-neutralizing antibody, was generated from mouse splenic lymphocytes that were fused to a murine myeloma cell line. Corresponding light and heavy chain variable domain genes from the hybridoma were cloned and sequenced. Three CDRs of MAb 1129 light chain and three CDRs of MAb heavy chain were transplanted on to corresponding light and heavy chain frameworks of a human IgG1 antibody. The resultant MAb is immunologically indistinguishable from a completely human IgG1 antibody.

\section{Pharmacologic/Pharmacodynamic Effects}

Mapping studies have shown that palivizumab binds to a conserved neutralizing epitope in the A region of the F glycoprotein. ${ }^{24}$ The mechanism whereby palivizumab inhibits viral replication was evaluated in various cellular assays. ${ }^{35}$ Palivizumab did not alter the attachment of RSV or the ability of the F protein to interact with target cells but was shown to inhibit virus transcription and block F protein-mediated cellto-cell fusion. No effect on reduction of viral budding was observed. Studies in the cotton rat established that palivizumab neutralized both A and B strains of RSV and was 50-100 times more potent than RSV-IGIV as determined by microneutralization and fusion-inhibition assays. ${ }^{25} \mathrm{~A}$ reduction in pulmonary RSV titer of $99 \%$ (ie, 2-log reduction versus control) was achieved at mean palivizumab serum levels of 25-30 $\mathrm{\mu g} / \mathrm{mL}$, with complete inhibition noted at serum concentrations $\geq 40 \mu \mathrm{g} / \mathrm{mL}$. No enhancement of viral replication or virusinduced histopathology was observed either after primary RSV infection or rechallenge with RSV. Surveillance of RSV clinical isolates for palivizumab-resistant mutants showed that palivizumab bound to all isolates tested and no resistance was detected. ${ }^{36}$

Pharmacokinetic analyses following intramuscular administration of palivizumab $15 \mathrm{mg} / \mathrm{kg}$ in the intended population have revealed a half-life consistent with that of an IgG1 antibody (ie, approximately 20-30 days) and highly variable serum trough concentrations 30 days following each dose. ${ }^{12,37,38}$ Serum RSVneutralizing antibody titers closely paralleled serum palivizumab concentrations. ${ }^{39}$ The effects of palivizumab on RSV titers in the upper and lower respiratory tract were studied following intravenous administration in hospitalized children with severe RSV disease. ${ }^{40}$ Palivizumab 
significantly reduced RSV titers in the lower respiratory tract but had no significant effect on RSV replication in the nasopharynx. This finding is consistent with earlier observations that showed the serum neutralizing antibody titer necessary to lower nasal virus concentration by $99 \%$ was 10 times greater than that required to reduce lung virus concentrations to a similar degree. ${ }^{20}$

\section{Prevention of RSV Disease in Premature Children and Those with CLD}

The pivotal study (termed IMpact-RSV) that established the safety and effectiveness of palivizumab in high-risk children was a doubleblind, 2:1 placebo-controlled trial conducted at 139 centers in the United States, the United Kingdom, and Canada. ${ }^{12}$ A total of 1502 highrisk children with prematurity ( $\leq 35$ weeks gestational age [GA] and $\leq 6$ months of age) or CLD ( $\leq 24$ months of age and medically treated for CLD within the previous 6 months) were randomized to treatment with five monthly intramuscular injections of palivizumab $15 \mathrm{mg} / \mathrm{kg}$ or placebo during a single RSV season. The primary efficacy endpoint was reduction in laboratory confirmed hospitalization for RSV; secondary endpoints probed characteristics about hospitalization.

Treatment groups were equally represented in terms of demographic characteristics and compliance with therapy. Monthly prophylaxis with palivizumab was associated with significant reductions in RSV hospitalization overall (ie, 55\%), for each high-risk group, and for specific subgroups according to age and pulmonary status (Table 2). Of children who were hospitalized, those randomized to palivizumab experienced significantly fewer total days of

Table 2. Effectiveness of palivizumab versus placebo for the reduction of respiratory syncytial virus (RSV)-related hospitalization in premature children and those with chronic lung disease of prematurity. ${ }^{12,33}$

\begin{tabular}{lccc}
\hline Treatment group & $\begin{array}{c}\text { Palivizumab, } \\
n=\mathbf{1 0 0 2}\end{array}$ & $\begin{array}{c}\text { Placebo, } \\
n=500\end{array}$ & Palivizumab overall reduction \\
\hline All infants $(n=1502)$ & $4.8 \%$ & $10.6 \%$ & $55 \%(P=0.00004)$ \\
Infants with CLD $(n=762)$ & $7.9 \%$ & $12.8 \%$ & $39 \%(P=0.038)$ \\
Infants $<32$ weeks $(n=1111)$ & $5.8 \%$ & $11.0 \%$ & $47 \%(P=0.003)$ \\
Preterm infants born at 32-35 weeks $(n=373)$ & $2.0 \%$ & $9.8 \%$ & $80 \%(P=0.02)$ \\
Infants without CLD $(n=740)$ & $1.8 \%$ & $8.1 \%$ & $78 \%(P<0.001)$ \\
Preterm infants without CLD born at & $1.8 \%$ & $10.0 \%$ & $82 \%(P<0.001)$ \\
32-35 weeks $(n=335)$ & & & \\
\hline Hospitalized children & & & \\
\hline Total days hospitalized per 100 children & 36.4 & 62.6 & $P<0.001$ \\
Days with increased $\mathrm{O}_{2}$ & 30.3 & 50.6 & $P=0.026$ \\
Patients admitted to an ICU & $1.3 \%$ & $3.0 \%$ & $P=0.280$ \\
Incidence of mechanical ventilation & $0.2 \%$ & $0.7 \%$ & $P=0.210$ \\
Total days of mechanical ventilation & 1.7 & 8.4 &
\end{tabular}

$\mathrm{CLD}=$ chronic lung disease of prematurity; $\mathrm{ICU}=$ intensive care unit. 
hospitalization, days with increased oxygen, RSV-related admissions to the intensive-care unit (ICU), and total days in an ICU (Table 2). However, there were no significant differences in incidence of mechanical ventilation or total days of mechanical ventilation, which was probably related to the small number of patients represented. Common adverse events reported in this trial included fever, nervousness, injection site reaction, and diarrhea. A similar incidence of children reported adverse events judged by the investigator to be related to the study drug ( $11 \%$ versus $10 \%$ for palivizumab and placebo, respectively), and only $0.3 \%$ of children given palivizumab discontinued therapy. The potential immunogenicity of palivizumab was evaluated by determination of nonspecific serum antibody binding. Low levels of palivizumab antidrug antibodies were detected, and there were no signals indicative of a safety risk. Although trough serum palivizumab concentrations increased with each dose, extreme individual variability was noted and no correlation could be made between trough serum levels and hospitalization. Results from this study formed the basis for the initial licensure of palivizumab in the United States in June 1998 and in other world markets for the prevention of serious lower respiratory tract disease caused by RSV in infants with CLD and infants with a history of premature birth ( $\leq 35$ weeks GA).

\section{Prevention of RSV Disease in Children with Hemodynamically Significant CHD}

Because high-risk children with CHD were excluded from the IMpact-RSV trial, a follow-up postmarketing study was conducted to initially evaluate the safety of palivizumab in these children and was subsequently expanded to include numerous efficacy parameters. ${ }^{13}$ The primary outcome objective of this multinational, randomized, double-blind trial was to compare the safety and efficacy of palivizumab $15 \mathrm{mg} / \mathrm{kg}$ administered monthly ( $n=639$ ) by intramuscular injection for five doses

Table 3. Effectiveness of palivizumab versus placebo for the reduction of respiratory syncytial virus (RSV)-related hospitalization in children with congenital heart disease (CHD). ${ }^{13,37}$

\begin{tabular}{lccc}
\hline Treatment group & $\begin{array}{c}\text { Palivizumab, } \\
n=639\end{array}$ & $\begin{array}{c}\text { Placebo, } \\
n=648\end{array}$ & $\begin{array}{c}\text { Palivizumab } \\
\text { overall reduction }\end{array}$ \\
\hline All children & $5.3 \%$ & $9.7 \%$ & $45 \%(P=0.003)$ \\
Children with cyanotic CHD & $5.6 \%$ & $7.9 \%$ & $29 \%(P=0.25)$ \\
Children with acyanotic CHD & $5.0 \%$ & $11.8 \%$ & $58 \%(P=0.003)$ \\
Infants <6 months of age & $6.0 \%$ & $12.2 \%$ & $7.3 \%$ \\
Infants 6-12 months & $6.1 \%$ & $4.3 \%$ & \\
Children 1-2 years of age & $1.8 \%$ & & \\
\hline Hospitalized children & & 129.0 & $73 \%(P=0.014)$ \\
Total days hospitalized per 100 children & 57.4 & 101.5 & $46 \%(P=0.094)$ \\
Total days with increased ${ }_{2}$ per 100 children & 27.9 & $3.7 \%$ & $78 \%(P=0.080)$ \\
Patients admitted to an ICU & $2.0 \%$ & 71.2 & $41 \%(P=0.282)$ \\
Total days of ICU stay per 100 children & 15.9 & $2.2 \%$ & $88 \%(P=0.224)$ \\
Incidence of mechanical ventilation & $1.3 \%$ & 54.7 & \\
Total days of mechanical ventilation per 100 children & 6.5 & & \\
\hline
\end{tabular}

ICU =intensive care unit. 
with placebo in 1287 children $\leq 24$ months of age with hemodynamically significant CHD. Secondary endpoints were similar to those in the IMpact-RSV trial with respect to RSV hospitalization and also included a description of the effects of cardiac bypass on serum palivizumab concentrations.

There were no significant differences between groups with respect to any of the demographic characteristics, RSV risk factors, or classification of CHD. The majority (53\%) of all patients fell into the cyanotic stratum, and the distribution of cardiac lesions was balanced between treatment groups. The palivizumab group experienced a significant $45 \%$ relative reduction in RSV hospitalization rate compared with placebo (Table 3). Reductions in hospitalization were seen in both strata and were significantly reduced by $58 \%$ in patients in the acyanotic group who were administered palivizumab even though the study was not powered for subgroup analyses (Table 3). Significant differences in favor of palivizuamb were also observed for secondary endpoints of total days of hospitalization per 100 children and RSV hospital days with increased oxygen requirement per 100 children (Table 3). Common adverse events reported in this trial included: fever, upper respiratory tract infection, injection site reaction, infection, cyanosis, and arrhythmia but were not related to study drug. The proportion of children with adverse events was similar between treatment groups, and no child experienced a related adverse event that resulted in treatment discontinuation. Mean serum palivizumab concentrations were decreased by 58\% following cardiopulmonary bypass surgery and indicated that a supplemental dose should be given after the procedure. The results of this trial supported licensure of palivizumab in September 2003 for prevention of serious lower respiratory tract disease caused by RSV in children with hemodynamically significant CHD.

\section{Postmarketing Experience}

The Palivizumab Outcomes Registry was conducted over 4 years (2000-2004) to determine if real-world experience with palivizumab is similar to research findings. ${ }^{41,42}$ Data were collected on nearly 20,000 subjects, the majority $(88 \%)$ of whom were $<35$ weeks GA. The overall RSV hospitalization rate was $1.3 \%$ but increased twofold in children with cyanotic CHD. Although these were not controlled studies, the data confirm the findings of the registration trials in at-risk children.

\section{Palivizumab and Long-Term Wheezing}

A growing body of evidence suggests a causal link between early RSV infection and recurrent wheezing in some children. ${ }^{43}$ This has led to the speculation that prevention of early RSV infection might decrease the risk of recurrent wheezing. Simoes and coworkers found, in a prospective double-cohort study of preterm infants without chronic lung disease, that recurrent wheezing and physician-diagnosed recurrent wheezing were reduced by approximately 50\% in palivizumab-treated subjects compared with comparable untreated subjects over a 2-year follow-up period. ${ }^{44}$ A prospective, controlled, randomized trial to assess the impact of palivizumab prophylaxis on recurrent wheezing has not yet been conducted.

\section{MEDI-524/MOTAVIZUMAB}

Following the licensure of palivizumab, several technologies were employed to try to improve upon its biological function. Of the variants synthesized and tested for their pharmacokinetic and biodistribution properties in cynomolgus monkeys, motavizumab was selected as the lead clinical candidate. ${ }^{45-47}$ Motavizumab differs 
structurally from palivizumab through selective changes made in 13 amino acid sequences: six CDR changes and one framework change in the heavy chain, and five CDR changes and one framework change in the light chain. Overall, $98 \%$ of the amino acid sequences are identical in each MAb and both are made up of $95 \%$ human and $5 \%$ murine antibody sequences.

\section{Prevention of RSV Illness in High-Risk Children}

Three late-stage trials have been conducted to date with motavizumab in more than 9000 children at high-risk of serious RSV illness (Table 1). Head-to-head studies with palivizumab were performed in premature infants $\leq 6$ months of age at enrollment and children with CLD (study MI-CP117). ${ }^{14}$ A safety study was performed in children $\leq 24$ months of age with hemodynamically significant CHD (study MI-CP124). ${ }^{15}$ A third placebo-controlled motavizumab trial was undertaken in term Southwest American Indian children $\leq 6$ months of age (study MI-CP117), ${ }^{16}$ a population known to have a high risk for serious RSV disease. ${ }^{48}$ Each study employed a dosing regimen of motavizumab $15 \mathrm{mg} / \mathrm{kg}$ administered by intramuscular injection for five monthly doses during one RSV season and baseline demographic characteristics of enrolled subjects were generally well matched across trials.

Noninferiority efficacy was achieved for the primary endpoint in MI-CP110, and a trend toward lower RSV-associated hospitalization rates was observed but was not statistically significant (ie, $25 \%$ to $26 \%$ versus palivizumab in MI-CP110 and MI-CP124; $83 \%$ versus placebo in MI-CP117) and RSVrelated medically attended lower respiratory infection, a secondary endpoint (ie, 50\% versus palivizumab in MI-CP110 and MI-CP124; 71\% versus placebo in MI-CP117) were observed for motavizumab versus palivizumab. ${ }^{14-16}$ In a post hoc analysis of patients who were hospitalized, a statistically significant difference favoring motavizumab was observed in the number of patients who required mechanical ventilation $(0.1 \%$ versus $0.3 \% ; P=0.012)$ and in the duration of mechanical ventilation ( 0.5 versus 3.8 total days/100 patients; $P=0.012$ ). Values for duration of RSV hospitalization, number of patients who required increased supplemental oxygen and admission to the ICU, and duration of increased supplemental oxygen and ICU stay were all lower in the motavizumab group versus the palivizumab group, but these differences were not statistically significant between treatment groups.

The pattern and types of most adverse events with motavizumab were consistent with the underlying conditions in this high-risk population. When present, they were usually mild or moderate in severity. A higher incidence of skin adverse events among those given motavizumab versus those given palivizumab were observed and generally characterized as possible hypersensitivity reactions $(7.2 \%$ versus 5.1\%). At present, motavizumab is not licensed in any world market. A study evaluating the treatment of RSV disease with motavizumab is currently ongoing.

\section{MEDI-557}

Palivizumab and motavizumab both have a circulation half-life of approximately 3 weeks (ie, similar to IgG1) and are recommended to be administered monthly throughout the RSV season. Development of a long-lasting, anti-RSV MAb that could be given only once or twice during the RSV season is therefore desirable. Studies have shown that the neonatal Fc receptor (FcRn) plays a key role 
in prolonging and maintaining the serum IgG level. ${ }^{49}$ Binding of FcRn is $\mathrm{pH}$ dependent, binding tightly at $\mathrm{pH} 6$ but exhibiting almost no binding at $\mathrm{pH}$ 7.4. Researchers at MedImmune have re-engineered the human Fc region for improved affinity to human FcRn at $\mathrm{pH}$ 6. The pharmacokinetic and biodistribution properties of this molecule were tested in cynomolgus monkeys and showed a fourfold increase in serum half-life and bioavailability compared with motavizumab. ${ }^{50}$ The next step will be to test whether this pharmacokinetic profile is retained in humans. If successful, MEDI-557 could represent an advance in the prevention of RSV by potentially improving both efficacy and compliance. Further, if this long half-life technology is validated in humans, it may be applied to other prophylactic and therapeutic antibodies in the future.

\section{CONCLUSION}

RSV is unique among respiratory viruses in that it infects infants at an early age and subjects do not develop sufficient immunity to prevent subsequent reinfection. It is the primary cause of hospitalization in infants younger than 1 year in the United States. There are no RSV vaccines currently available for prevention of serious RSV illness, and none are likely to be licensed in the near future. Immunoprophylaxis with RSV-neutralizing antibody is the only means of prophylaxis against severe RSV in high-risk infants and has evolved from the intravenous administration of large volumes of RSV antibodyenriched polyclonal immune globulin to intramuscular administration of RSV-specific IgG MAb monthly throughout the RSV season. The development of future IgG MAbs is being considered to provide greater antiviral activity and/or be dosed less frequently than currently available therapy.

\section{ACKNOWLEDGMENTS}

The authors kindly acknowledge the assistance of Dr. Jay Bauman in the preparation of this manuscript. Dr. Bauman is a consultant to MedImmune and has received compensation for assistance in the preparation of this manuscript.

JRG is the guarantor for this article, and takes responsibility for the integrity of the work as a whole.

Open Access. This article is distributed under the terms of the Creative Commons Attribution Noncommercial License which permits any noncommercial use, distribution, and reproduction in any medium, provided the original author(s) and source are credited.

\section{REFERENCES}

1. Hemming VG, Prince GA, Groothuis JR, Siber GR. Hyperimmune globulins in prevention and treatment of respiratory syncytial virus infections. Clin Microbiol Rev. 1995;8:22-33.

2. Lamprecht CL, Krause HE, Mufson MA. Role of maternal antibody in pneumonia and bronchiolitis due to respiratory syncytial virus. J Infect Dis. 1976;134:211-217.

3. Henderson FW, Collier AM, Clyde WA Jr, Denny FW. Respiratory-syncytial-virus infections, reinfections and immunity. A prospective, longitudinal study in young children. N Engl J Med. 1979;300:530-534.

4. Kasel JA, Walsh EE, Frank AL, Baxter BD, Taber LH, Glezen WP. Relation of serum antibody to glycoproteins of respiratory syncytial virus with immunity to infection in children. Viral Immunol. 1987;1:199-205.

5. Ottolini MG, Burnett MW. History of U.S. military contributions to the study of respiratory infections. Mil Med. 2005;170:66-70.

6. Hemming VG, Rodriguez W, Kim HW, et al. Intravenous immunoglobulin treatment of respiratory syncytial virus infections in infants and young children. Antimicrob Agents Chemother. 1987;31:1882-1886. 
7. Groothuis JR, Levin MJ, Rodriguez W, et al. Use of intravenous gamma globulin to passively immunize high-risk children against respiratory syncytial virus: safety and pharmacokinetics. The RSVIG Study Group. Antimicrob Agents Chemother. 1991;35:1469-1473.

8. Meissner HC, Fulton DR, Groothuis JR, et al. Controlled trial to evaluate protection of highrisk infants against respiratory syncytial virus disease by using standard intravenous immune globulin. Antimicrob Agents Chemother. 1993;37:1655-1658.

9. Groothuis JR, Simoes EA, Levin MJ, et al. Prophylactic administration of respiratory syncytial virus immune globulin to high-risk infants and young children. The Respiratory Syncytial Virus Immune Globulin Study Group. N Engl J Med. 1993;329:1524-1530.

10. The PREVENT Study Group. Reduction of respiratory syncytial virus hospitalization among premature infants and infants with bronchopulmonary dysplasia using respiratory syncytial virus immune globulin prophylaxis. Pediatrics. 1997;99:93-99.

11. Simoes EA, Sondheimer HM, Top FH Jr, et al. Respiratory syncytial virus immune globulin for prophylaxis against respiratory syncytial virus disease in infants and children with congenital heart disease. The Cardiac Study Group. J Pediatr. 1998;133:492-499.

12. The IMpact-RSV Study Group. Palivizumab, a humanized respiratory syncytial virus monoclonal antibody, reduces hospitalization from respiratory syncytial virus infection in high-risk infants. Pediatrics. 1998;102:531-537.

13. Feltes TF, Cabalka AK, Meissner $\mathrm{HC}$, et al. Palivizumab prophylaxis reduces hospitalization due to respiratory syncytial virus in young children with hemodynamically significant congenital heart disease. J Pediatr. 2003;143:532-540.

14. Carbonell-Estrany X, Simoes EA, Dagan R, et al. Motavizumab for prophylaxis of respiratory syncytial virus in high-risk children: a noninferiority trial. Pediatrics. 2010;125:e35-51.

15. Feltes TF, Sondheimer HM, Harris BS, et al. A randomized controlled trial of RSV prophylaxis with motavizumab vs palivizumab in young children with hemodynamically significant congenital heart disease (CHD). Paper presented at: Pediatric Academic Societies Annual Meeting; May 1-4, 2010; Vancouver, BC, Canada.
16. Chandran A, Millar EV, Weatherholtz R, et al. Safety and efficacy of motavizumab in the prevention of RSV disease in healthy infants. Paper presented at: American Pediatric Society/77th Annual Meeting for the Society for Pediatric Research; May 4, 2008; Honolulu, HI, USA.

17. Prince GA, Hemming VG, Horswood RL, Chanock RM. Immunoprophylaxis and immunotherapy of respiratory syncytial virus infection in the cotton rat. Virus Res. 1985;3:193-206.

18. Hemming VG, Prince GA, Horswood RL, et al. Studies of passive immunotherapy for infections of respiratory syncytial virus in the respiratory tract of a primate model. J Infect Dis. 1985;152:1083-1087.

19. Siber GR, Leszcynski J, Pena-Cruz V, et al. Protective activity of a human respiratory syncytial virus immune globulin prepared from donors screened by microneutralization assay. J Infect Dis. 1992;165:456-463.

20. Siber GR, Leombruno D, Leszczynski J, et al. Comparison of antibody concentrations and protective activity of respiratory syncytial virus immune globulin and conventional immune globulin. J Infect Dis. 1994;169:1368-1373.

21. Rodriguez WJ, Gruber WC, Welliver RC, et al. Respiratory syncytial virus (RSV) immune globulin intravenous therapy for RSV lower respiratory tract infection in infants and young children at high risk for severe RSV infections: Respiratory Syncytial Virus Immune Globulin Study Group. Pediatrics. 1997;99:454-461.

22. Ogra PL. Respiratory syncytial virus: the virus, the disease and the immune response. Paediatr Respir Rev. 2004;5(Suppl. A):S119-126.

23. Ruuskanen O, Ogra PL. Respiratory syncytial virus. Curr Probl Pediatr. 1993;23:50-79.

24. Beeler JA, van Wyke Coelingh K. Neutralization epitopes of the $\mathrm{F}$ glycoprotein of respiratory syncytial virus: effect of mutation upon fusion function. J Virol. 1989;63:2941-2950.

25. Johnson S, Oliver C, Prince GA, et al. Development of a humanized monoclonal antibody (MEDI-493) with potent in vitro and in vivo activity against respiratory syncytial virus. J Infect Dis. 1997;176:1215-1224.

26. Tempest PR, Bremner P, Lambert M, et al. Reshaping a human monoclonal antibody to inhibit human respiratory syncytial virus infection in vivo. Biotechnology (NY). 1991;9:266-271. 
27. Weltzin R, Traina-Dorge V, Soike K, et al. Intranasal monoclonal IgA antibody to respiratory syncytial virus protects rhesus monkeys against upper and lower respiratory tract infection. J Infect Dis. 1996;174:256-261.

28. OraVax Reports Results from Phase III Trial of HNK20 Nosedrop for Respiratory Syncytial Virus in Infants [press release]. Cambridge (MA): OraVax; March 19, 1997.

29. Davis CB, Hepburn TW, Urbanski JJ, et al. Preclinical pharmacokinetic evaluation of the respiratory syncytial virus-specific reshaped human monoclonal antibody RSHZ19. Drug Metab Dispos. 1995;23:1028-1036.

30. Everitt DE, Davis CB, Thompson $\mathrm{K}$, et al. The pharmacokinetics, antigenicity, and fusioninhibition activity of RSHZ19, a humanized monoclonal antibody to respiratory syncytial virus, in healthy volunteers. J Infect Dis. 1996;174:463-469.

31. Fisher RG, Johnson JE, Dillon SB, Parker RA, Graham BS. Prophylaxis with respiratory syncytial virus F-specific humanized monoclonal antibody delays and moderately suppresses the native antibody response but does not impair immunity to late rechallenge. J Infect Dis. 1999;180:708-713.

32. Wyde PR, Moore DK, Hepburn T, et al. Evaluation of the protective efficacy of reshaped human monoclonal antibody RSHZ19 against respiratory syncytial virus in cotton rats. Pediatr Res. 1995;38:543-550.

33. Johnson S, Griego SD, Pfarr DS, et al. A direct comparison of the activities of two humanized respiratory syncytial virus monoclonal antibodies: MEDI-493 and RSHZ19. J Infect Dis. 1999;180:35-40.

34. Meissner HC, Groothuis JR, Rodriguez WJ, et al. Safety and pharmacokinetics of an intramuscular monoclonal antibody (SB 209763) against respiratory syncytial virus (RSV) in infants and young children at risk for severe RSV disease. Antimicrob Agents Chemother. 1999;43:1183-1188.

35. Huang K, Incognito L, Cheng X, Ulbrandt ND, $\mathrm{Wu} \mathrm{H}$. Respiratory syncytial virus-neutralizing monoclonal antibodies motavizumab and palivizumab inhibit fusion. J Virol. 2010;84:8132-8140.

36. DeVincenzo JP, Hall CB, Kimberlin DW, et al. Surveillance of clinical isolates of respiratory syncytial virus for palivizumab (Synagis)-resistant mutants. J Infect Dis. 2004;190:975-978.

37. Saez-Llorens X, Castano E, Null D, et al. Safety and pharmacokinetics of an intramuscular humanized monoclonal antibody to respiratory syncytial virus in premature infants and infants with bronchopulmonary dysplasia. The MEDI-493 Study Group. Pediatr Infect Dis J. 1998;17:787-791.

38. Wu SY, Bonaparte J, Pyati S. Palivizumab use in very premature infants in the neonatal intensive care unit. Pediatrics. 2004;114:e554-556.

39. Subramanian KN, Weisman LE, Rhodes $\mathrm{T}$, et al. Safety, tolerance and pharmacokinetics of a humanized monoclonal antibody to respiratory syncytial virus in premature infants and infants with bronchopulmonary dysplasia. MEDI-493 Study Group. Pediatr Infect Dis J. 1998;17:110-115.

40. Malley R, DeVincenzo J, Ramilo O, et al. Reduction of respiratory syncytial virus (RSV) in tracheal aspirates in intubated infants by use of humanized monoclonal antibody to RSV F protein. J Infect Dis. 1998;178:1555-1561.

41. Cohen SA, Zanni R, Cohen A, Harrington M, Vanveldhuisen P, Boron ML. Palivizumab use in subjects with congenital heart disease: results from the 2000-2004 Palivizumab Outcomes Registry. Pediatr Cardiol. 2008;29:382-387.

42. Frogel M, Nerwen C, Cohen A, VanVeldhuisen $\mathrm{P}$, Harrington $\mathrm{M}$, Boron $\mathrm{M}$. Prevention of hospitalization due to respiratory syncytial virus: results from the Palivizumab Outcomes Registry. J Perinatol. 2008;28:511-517.

43. Kim EY, Battaile JT, Patel AC, et al. Persistent activation of an innate immune response translates respiratory viral infection into chronic lung disease. Nat Med. 2008;14:633-640.

44. Simoes EA, Groothuis JR, Carbonell-Estrany X, et al. Palivizumab prophylaxis, respiratory syncytial virus, and subsequent recurrent wheezing. J Pediatr. 2007;151:34-42.

45. Wu H, Pfarr DS, Johnson S, et al. Development of motavizumab, an ultra-potent antibody for the prevention of respiratory syncytial virus infection in the upper and lower respiratory tract. J Mol Biol. 2007;368:652-665.

46. Wu H, Pfarr DS, Losonsky GA, Kiener PA. Immunoprophylaxis of RSV infection: advancing from RSV-IGIV to palivizumab and motavizumab. Curr Top Microbiol Immunol. 2008;317:103-123. 
47. Wu H, Pfarr DS, Tang Y, et al. Ultra-potent antibodies against respiratory syncytial virus: effects of binding kinetics and binding valence on viral neutralization. J Mol Biol. 2005;350:126-144.

48. Bockova J, O’Brien KL, Oski J, et al. Respiratory syncytial virus infection in Navajo and White Mountain Apache children. Pediatrics. 2002;110:e20.
49. Junghans RP. Finally! The Brambell receptor (FCRB). Mediator of transmission of immunity and protection from catabolism for IgG. Immunol Res. 1997;16:29-57.

50. Dall'Acqua WF, Kiener PA, Wu H. Properties of human IgG1s engineered for enhanced binding to the neonatal Fc receptor (FcRn). J Biol Chem. 2006;281:23514-23524. 